\title{
DYNAMICS OF QUERCETIN FORMATION IN ONION (ALLIUM CEPA L.) DURING VEGETATION
}

\author{
J. BystrickA ${ }^{a *}$, J. Musilova ${ }^{\mathrm{a}}$, J. Tomas ${ }^{\mathrm{a}}$, J. Noskovic ${ }^{\mathrm{b}}$, E. DAdÁKova ${ }^{\mathrm{c}}$ and P. Kavalcova ${ }^{\mathrm{a}}$ \\ ${ }^{a}$ Department of Chemistry, Faculty of Biotechnology and Food Sciences, \\ ${ }^{b}$ Department of Chemistry, Faculty of Agrobiology and Food Resources \\ Slovak University of Agriculture in Nitra; Tr. A Hlinku 2, 94976 Nitra. Slovak Republic \\ ${ }^{\mathrm{c}}$ Chemistry Department, Faculty of Agriculturae, University of South Bohemia, Studentska 13, \\ 37005 České Budějovice. Czech Republic
}

(Received: 7 June 2013; accepted: 16 July 2013)

\begin{abstract}
Onion bulbs (Allium cepa L.) are good sources of flavonoids. The aim of this study was to analyse the changes in dynamics of quercetin formation in three varieties of onions (white, yellow, and red) during the vegetation period. Quercetin content was determined after acid hydrolysis (1.2 $\mathrm{M} \mathrm{HCl}$ in $50 \%$ aqueous methanol) by high-performance liquid chromatography (HPLC). The content of total phenolics was determined using Folin-Ciocalteu reagent (FCR) according to LACHMAN and co-workers (2003). The content of polyphenols in onion ranged from 2893 to 6052 $\mathrm{mg} \mathrm{kg}^{-1}$ and the content of quercetin ranged from 52.44 to $280.72 \mathrm{mg} \mathrm{kg}^{-1}$ in fresh matter. The highest content of polyphenols and quercetin was found in the red variety. According to statistical analysis the dynamic of quercetin formation in all cultivars had statistically moderate $(\mathrm{P}<0.05)$ increasing tendency. Increasing content of polyphenols was accompanied with slight increase of quercetin, but the differences remained insignificant $(\mathrm{P}<0.05)$.
\end{abstract}

Keywords: onion, quercetin, total polyphenolics, dynamics

Allium genus vegetables belong to a very important group of vegetables in the Slovak Republic. Onions (Allium cepa L.) are one of the world's oldest cultivated vegetables and are the second most produced vegetable crop after tomatoes (Griffiths et al., 2002). This vegetable is often classified as medicinal plant and also has significance as spice plant of high dietary value. From the point of view of the consumers and agricultural producers the most widespread type of Allium vegetables is onion (Allium cepa L.). The main production areas are China, Iran, India, and the United States.

Onion (Allium cepa L.) has a great importance in human nutrition and has been recognized as an important source of valuable phytonutrients as flavonoids, fructooligosaccharides, thiosulphinates and other sulphur compounds (SLimeSTAD et al., 2007). Onion is mainly rich in flavonoids. The amount of phenolic compounds significantly changes during the maturation process. WANG and co-workers (2009) found that amounts of cyanidinbased anthocyanins increased during fruit ripening, but other polyphenols, such as ellagic acid, quercetin 3-glucoside, quercetin derivative, and kaempferol 3-glucuronide, significantly decreased during fruit ripening. The changes in the rutin content are often connected with the developmental stage of the crop. In common buckwheat the rutin content in leaves increases with the age of the plant, is at the maximum at the stage of maturity or at the stage of full flowering in case of dry weather conditions after flowering, and in stems the rutin content slightly decreases (KaLINOva et al., 2006). Flavonoids improve blood circulation, reduce inflammatory processes and block the development of cancer cells (CHENG et al., 2003;

\footnotetext{
* To whom correspondence should be addressed. Phone: +420 37641 4353; e-mail: judita.bystricka@centrum.sk
} 
BESTWICK et al., 2007). In addition to quercetin, onion also contains flavones luteolin and kempferol (LANZOTTI, 2006). Quercetin is the most represented polyphenolic compound of flavonols. Quercetin (3,3',4',5,7-pentahydroxyflavon) is found in free and bound form (RHODES \& PRICE, 1996). Quercetin in onions occurs mainly as a mixture of $4^{\prime}$-monoglucoside and $3,4^{\prime}$-diglucoside and a number of studies indicate that these have a much greater bioavailability than quercetin from other food sources containing different sugar moieties (ARTs et al., 2004). Mono- and diglucosides quercetin represent 93\% of total flavonols in onion (LOMBARD et al., 2005). Quercetin was reported to have protective effects in reducing the risk of cardiovascular disease and to act as anti-cancer and antioxidant agent due to its antiprostanoid and anti-inflammatory responses and to decrease the rate of DNA degradation (CRYstal et al., 2003).

The aim of the experiment was to study the dynamics of changes in quercetin content during vegetation and total polyphenols content at the end of the growing season in three cultivars of onions (Allium cepa L.).

\section{Materials and methods}

\subsection{Plant material}

Three cultivars of onions: Kamal F1 (red), Sherpa (yellow), and Stardust (white) were obtained directly from a producer - PD Madunice, Slovak Republic. The investigated onion cultivars were conventionally cultivated in the same locality under the same conditions. The soil type of locality Madunice is fluvisols. Annual average temperature is $9.2{ }^{\circ} \mathrm{C}$, the average annual rainfall $577 \mathrm{~mm}$. Only NPK fertilization was used for the achievement of favourable soil macroelements content.

\subsection{Chemicals and extraction}

Folin-Ciocalteu assay and gallic acid were purchased from Merck (Darmstadt, Germany).

Sodium carbonate, methanol and 2,2-diphenyl-1-picrylhydrazyl radical (DPPH) were obtained from Sigma-Aldrich (St. Louis, MO, USA).

Methanol extracts were prepared by adding $100 \mathrm{ml}$ of $80 \%$ methanol to $10 \mathrm{~g}$ milled sample and was extracted in the Twisselmann apparatus for $12 \mathrm{~h}$. Samples were then filtered through filter paper (130 $\mathrm{g} \mathrm{m}^{-2}$, Filtrak, Thermalbad Wiesenbad, Germany) and kept at $8{ }^{\circ} \mathrm{C}$ for further analysis.

\subsection{Total polyphenolic content (TPC)}

The total polyphenolic content was assessed by the method used by LACHMAN and co-workers (2003) employing the reduction of a phosphowolframate-phosphomolybdate complex to blue products by phenolic compounds. Briefly, an aliquot of the extract, blank, or standard was placed in a $50 \mathrm{ml}$ flask, where the Folin-Ciocalteu reagent $(2.5 \mathrm{ml})$ was added and the mixture was allowed to react for 3 min under continuous stirring, then a solution of sodium carbonate $(7.5 \mathrm{ml})$ was added and mixed thoroughly. The volume was then made up to $50 \mathrm{ml}$ with distilled water and left standing at room temperature for $2 \mathrm{~h}$. The absorbance was measured at $765 \mathrm{~nm}$ using Shimadzu UV-1800 spectrophotometer (Japan). Results were expressed as mg gallic acid equivalents (GAE) per kg fresh weight (FW). 


\subsection{Quercetin content}

$10 \mathrm{~g}$ of onion slices were homogenized with $40 \mathrm{ml}(62.5 \%)$ methanol. To this, $10 \mathrm{ml}$ of $6 \mathrm{M}$ $\mathrm{HCl}$ was added carefully to give a total volume of $50 \mathrm{ml}$. The extraction mixture was thereafter heated to $90{ }^{\circ} \mathrm{C}$ in a thermostat for $2 \mathrm{~h}$. After cooling, the homogenate was filtered through red filter paper $\left(125 \mathrm{~mm}, 84 \mathrm{~g} \mathrm{~m}^{-2}\right.$, Grade 1292). Subsequently, the extract was filtered through a $0.45-\mu \mathrm{m}$ filter (Frisenette ApS, Denmark).

The filtrate was injected into a high performance liquid chromatography (HPLC) system that consisted of an Alliance 2695 chromatograph (Waters, Milford, USA), a LiChroCART Purospher RP C18 column ( $5 \mu \mathrm{m}, 250 \times 4.6 \mathrm{~mm}$; Merck, Darmstadt, Germany), and a DAD 2996 UV detector (Waters, Milford, USA). The column temperature was $30^{\circ} \mathrm{C}$. A gradient elution of the mobile phase was used with a flow rate of $1 \mathrm{ml} \mathrm{min}^{-1}$. Solvent A was acetonitrile, and solvent $\mathrm{B}$ was $0.1 \%$ phosphoric acid. The solvent gradient was as follows: the concentration of solvent A was $40 \%$ for the first $3 \mathrm{~min}, 5 \%$ for the next $5 \mathrm{~min}$, and $5 \%$ for an additional $2 \mathrm{~min}$. The concentration of solvent B was $60 \%$ for the first $3 \mathrm{~min}, 95 \%$ for the next $5 \mathrm{~min}$, and $95 \%$ for an additional $2 \mathrm{~min}$. The presence of quercetin was detected at $365 \mathrm{~nm}$, and the content was calculated on the basis of the calibration curve of quercetin standards (Acros Organics, Waltham, USA) prepared in methanol (gradient elution grade; Sigma-Aldrich Corporation, St. Louis, MO, USA). Results were expressed as $\mathrm{mg} \mathrm{kg}^{-1} \mathrm{FW}$.

All determinations were realised in six replicates.

\subsection{Statistical analysis}

Statistical evaluation of all results was carried out in Microsoft Excel using regression and correlation analysis. Mean comparisons between cultivars were done by the LSD-test, $\mathrm{P}<0.05$.

\section{Results and discussion}

Onion has a great importance in human nutrition. It is a source of biologically active phytosubstances, such as quercetin, phenolic acids, and kaempferol glycosides (SELLAPPAN et al., 2002).

The process of quercetin content formation was observed in three onion cultivars (red, yellow, and white) during the vegetation period. The highest content of quercetin was measured in red cultivar at the beginning of the vegetation period $\left(280.7 \pm 1.7 \mathrm{mg} \mathrm{kg}^{-1}\right)$. The slight decrease in quercetin content against first collection (about 24\%) was recorded in second half of June $\left(213.3 \pm 2.1 \mathrm{mg} \mathrm{kg}^{-1}\right)$. Generally in June the dynamics of quercetin formation showed slightly increasing tendency. At the end of the vegetation period the measured values were $278.3 \pm 2.6 \mathrm{mg} \mathrm{kg}^{-1}$ (Table 1).

Similar progress in the dynamics of quercetin formation was determined in yellow and white cultivars, as well. The highest contents of quercetin were measured at the beginning and in the end of the vegetation period and the lowest in the second decade of June $(134.1 \pm 3.8$ $\mathrm{mg} \mathrm{kg}^{-1}$ and $52.44 \pm 4.28 \mathrm{mg} \mathrm{kg}^{-1}$, respectively).

The dynamics of quercetin formation during the vegetation period of onion showed statistically significant $(\mathrm{P}<0.05)$ increasing tendency (Figs 1, 2, and 3). 
Table 1. Content of quercetin in three cultivars of onions during vegetation $\left(\mathrm{mg} \mathrm{kg}^{-1}\right)$

\begin{tabular}{lccc}
\hline Cultivars of onions & White & Yellow & Red \\
\hline I. sampling & $92.13 \pm 3.91$ & $169.09 \pm 8.58$ & $280.72 \pm 1.72$ \\
II. sampling & $81.71 \pm 2.17$ & $150.49 \pm 10.61$ & $273.95 \pm 5.14$ \\
III. sampling & $68.53 \pm 2.89$ & $134.60 \pm 6.82$ & $261.47 \pm 1.53$ \\
IV. sampling & $52.44 \pm 4.28$ & $134.04 \pm 3.81$ & $213.31 \pm 2.14$ \\
V. sampling & $94.67 \pm 2.89$ & $164.28 \pm 5.01$ & $256.26 \pm 4.83$ \\
VI. sampling & $97.26 \pm 2.46$ & $171.64 \pm 5.53$ & $280.18 \pm 1.59$ \\
VII. sampling & $90.33 \pm 2.00$ & $170.04 \pm 5.12$ & $278.32 \pm 2.64$ \\
\hline
\end{tabular}

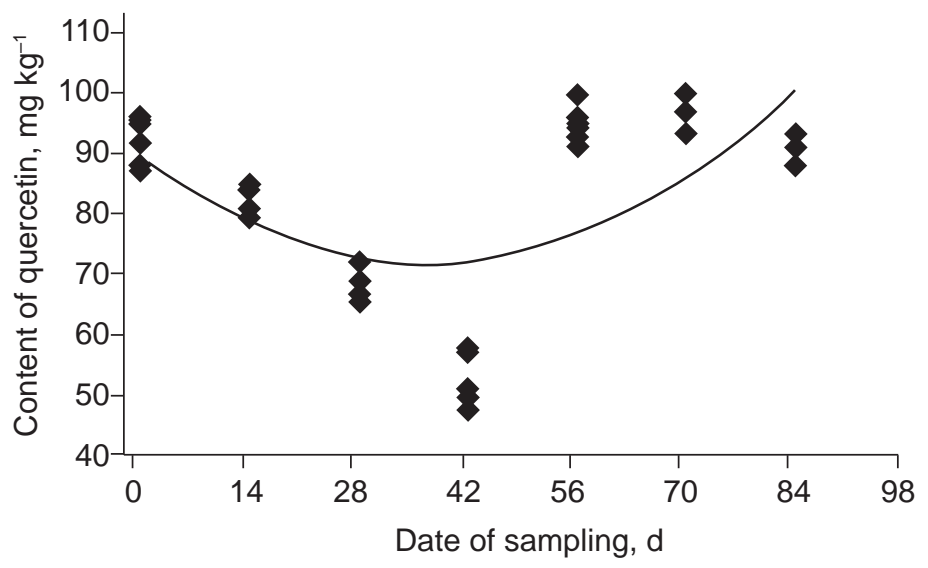

Fig. 1. Dynamics of quercetin formation in white onion $\left(y=0.0129 x^{2}-0.9803 x+90.53 ; R^{2}=0.38\right)$

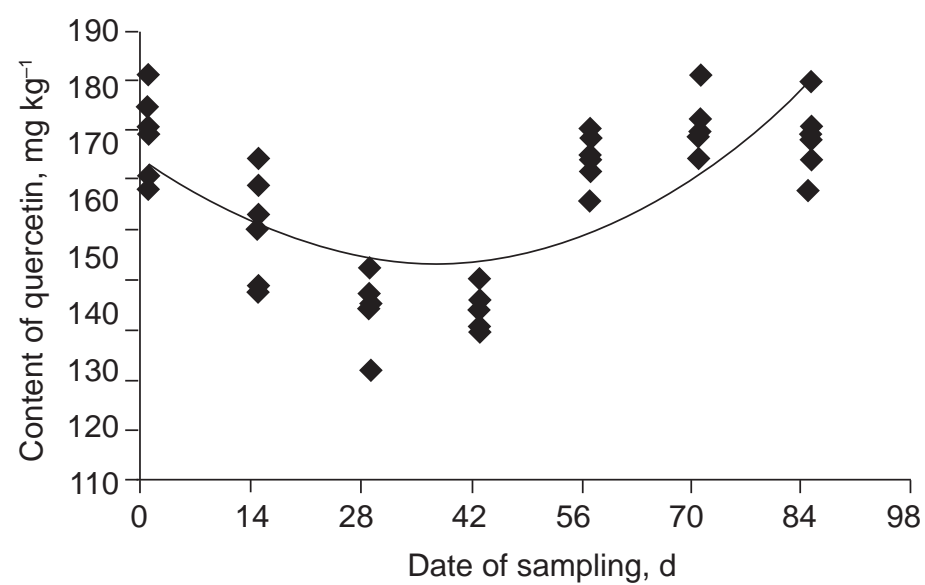

Fig. 2. Dynamics of quercetin formation in yellow onion $\left(\mathrm{y}=0.0161 \mathrm{x}^{2}-1.1886 \mathrm{x}+165.15 ; \mathrm{R}^{2}=0.537\right)$ 


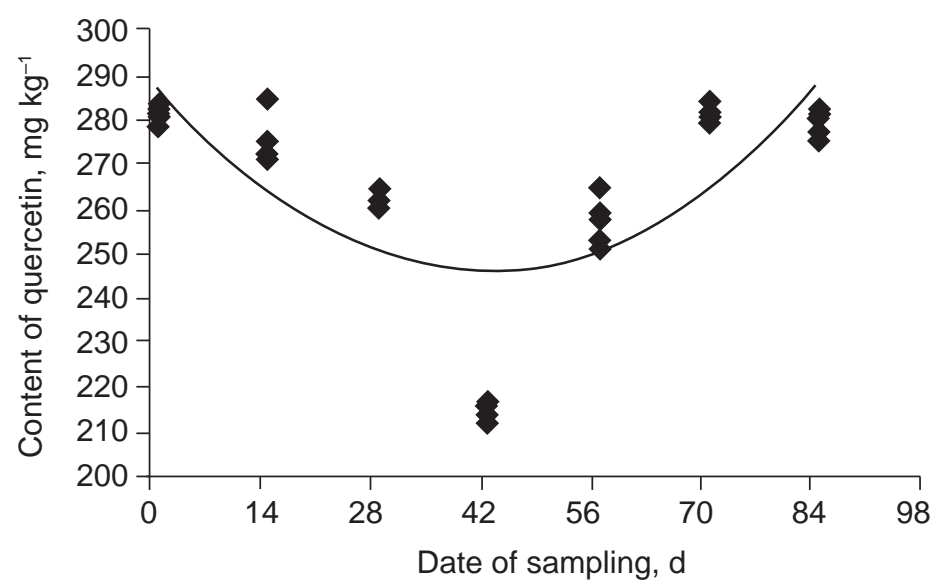

Fig. 3. Dynamics of quercetin formation in red onion $\left(y=0.0236 x^{2}-2.0305 x+288.6 ; R^{2}=0.5087\right)$

Our results correspond with those published by Horbowicz and KotLinsKa (2001). Authors found the highest content of quercetin in the first vegetation phase followed by its decrease and before harvest in July again a slight increase. PATIL and co-workers (1995a) measured various contents of quercetin in particular growth phases, while in the first and final phases the authors found similar values. The values during the observed period ranged from $54 \mathrm{mg} \mathrm{kg}^{-1}$ to $286 \mathrm{mg} \mathrm{kg}^{-1} \mathrm{FW}$. Higher values of quercetin content in onion from $185 \mathrm{mg} \mathrm{kg}^{-1}$ to $1917 \mathrm{mg} \mathrm{kg}^{-1} \mathrm{FW}$ were reported by WiczKowsKI and co-workers (2003), which could be caused by the different cultivars used in the experiment, the different soil composition and local microclimatic environment. The results obtained in our experiment suggest that the content of quercetin during the whole vegetation period, mainly in June, was probably influenced by the intensity of solar radiation. Several studies showed a significant impact of the intensity of sunlight on quercetin content in selected cultivars of onions (PATIL et al., 1995a; Mogren et al., 2007). This fact was also confirmed by our results, as in the second half of June the highest precipitation amount was recorded, which is reflected in the quercetin content of the onion during this month.

Another parameter evaluated at the end of the vegetation period was the content of total polyphenols. The highest value of this parameter was measured in the red cultivar Kama1 F1 (6052 $\left.\pm 267 \mathrm{mg} \mathrm{kg}^{-1}\right)$. Our results are similar to those published by Lu and co-workers (2011). PRAKASH and co-workers (2007) reported values of polyphenols in onion in the range of $4600-74100 \mathrm{mg} \mathrm{kg}^{-1}$. In this study the content of polyphenols in the yellow cultivar was $4310 \pm 536 \mathrm{mg} \mathrm{kg}^{-1}$. The lowest content was measured in white cultivar Stardust $(2893 \pm 327$ $\mathrm{mg} \mathrm{kg}^{-1}$ ). The presented values show that onion is a rich source of polyphenolic substances (Table 2).

According to the data obtained from the literature (Patil et al., 1995b; MarotTi \& PICCAGLIA, 2002) the polyphenolic content in onion depends on genetic factors, environmental conditions (temperature, light, availability of water and nutrients), agrotechnical practice, and after-harvest conditions. The correlation between total polyphenolic content and antioxidant activity has been widely studied in different foodstuffs such as fruit and vegetables. To our knowledge there is lack of evidence in the published data concerning correlations between total polyphenolic content and content of quercetin. In our study 
increase of total polyphenolic content was followed by a slight increase in the content of quercetin in all studied onion cultivars, however, without statistical differences $(\mathrm{P}>0.05)$. Our results differ from those published by NowAK and GAwLIK-DziKi (2007), where the authors found statistically significant positive correlation between quercetin and total flavonols content. The results of the present study require further experiments to complete the whole task. The research on the field of antioxidant properties of substances found in onion and other vegetables and its protection effect will be worthy of further investigation.

Table 2. Total content of polyphenols, $\mathrm{mg} \mathrm{kg}-1$, in $\mathrm{cv}$. of onions

\begin{tabular}{lccc}
\hline Cultivars of onions & White & Yellow & Red \\
\hline Quercetin & $90.33 \pm 2.00$ & $170.40 \pm 5.12$ & $278.32 \pm 2.64$ \\
$\begin{array}{l}\text { Total polyphenols } \\
\text { (except quercetin) }\end{array}$ & $2802 \pm 328$ & $4139 \pm 532$ & $5773 \pm 230$ \\
Total polyphenols & $2893 \pm 327$ & $4310 \pm 536$ & $6052 \pm 229$ \\
\hline
\end{tabular}

\section{Conclusions}

The present study indicates that onion is a rich source of bioactive components such as polyphenolic substances. From polyphenols onion contains mainly quercetin that possesses anticarcinogenic and antioxidant properties. Based on our results, the order of quercetin content in various cultivars of onion was: red (Kamal F) > yellow (Sherpa) $>$ white (Stardust). The highest content of quercetin was measured at the beginning and at the end of vegetation period in all onion cultivars. We conclude that genetic as well as climatic factors (intensity of sunlight) affect the quercetin content in onions.

The work was supported by scientific grant VEGA 1/0084/12, VEGA 1/0456/12, VEGA 1/0724/12 and by a producer PD-Madunice.

\section{References}

Arts, J.C.W., Sesink, A.L.A., FAassen-Peters, M. \& Hollman, P.C.H. (2004): The type of sugar moiety is a major determinant of the small intestinal uptake and subsequent biliary excretion of dietary quercetin glycosides. Brit. J. Nutr., 91, 841-847.

Bestwick, C.S., Milne, L. \& Duthie, S.J. (2007): Kaempferol induced inhibition of HL-60 cell growth results from a heterogeneous response, dominated by cell cycle alterations. Chem.-Biol. Interact., 170, 76-85.

Crystal, S., Lombard, K.A., Peffley, E.B. \& Liu, W.X. (2003): Genetic analysis of quercetin in onion (Allium cepa L.) 'Lady Raider'. Texas J. Agric. Nat. Res., 16, 24-28.

Cheng, J.Y., Kondo, K., Suzuki, Y., Ikeda, Y., Meng, X. \& Umemura, K. (2003): Inhibitory effects of total flavones of Hippophae rhamnoides $\mathrm{L}$. on thrombosis in mouse femoral artery and in vitro platelet aggregation. Life Sci., 72, 2263-2271.

Griffiths, G., Trueman, L., Crowther, T., Thomas, B. \& Smith, B. (2002): Onions - a global benefit to health. Phytother. Res., 16, 603-615.

Horbowicz, M. \& KotLinsKa, T. (2001): Changes of flavonols content during vegetation period and storage of shallot (Allium cepa var. Aggregatum). Vegetable Crops Res. Bull., 55, 81-90. 
Kalinova, J., Triska, J. \& VRchotova, N. (2006): Distribution of vitamin E, squalene, epicatechin and rutin in common buckwheat plants (Fagopyrum esculentum Moench). J. Agric. Fd Chem., 54, 5330-5335.

Lachman, J., Proněk, D., Hejtmánková, A., Dudjak, J., Pivec, V. \& Faitová, K. (2003): Total polyphenol and main flavonoid antioxidants in different onion (Allium cepa L.) varieties. Hort. Sci., 4, 142-147.

Lanzotti, V. (2006): The analysis of onion and garlic. J. Chromatog. A, 1112, 3-22.

Lombard, K., Peffley, E., Geoffriau, E., Thompson, L. \& Herring A. (2005): Quercetin in onion (Allium cepa L.) after heat-treatment simulating home preparation. J. Fd Compos. Anal., 18, 571-581.

Lu, X., Wang, J., Al-Qadiri, H.M., Ross, C.F., Powers, J.R., Tang, J. \& Rasco, B.A. (2011): Determination of total phenolic content and antioxidant capacity of onion (Allium cepa) and shallot (Allium oschaninii) using infrared spectroscopy. Fd Chem., 129, 637-644.

Marotti, M. \& Piccaglia, R. (2002): Characterization of flavonoids in different cultivars of onion (Allium cepa L.). J. Fd Sci., 67, 1229-1232.

Mogren, L.M., Olsson, M.E. \& Gertsson, U.E. (2007): Quercetin content in stored onions (Allium cepa L.): effects of storage conditions, cultivar, lifting time and nitrogen fertiliser level. J. Sci. Fd Agric., 87, 1595-1602.

Nowak, R. \& GAwlik-Dziki, U. (2007): Polyphenols of Rosa L. leaves extract and their radical scavenging activity. Naturforschung, 62, 32-38.

Patil, B.S., Pike, L.M. \& Yoo, K.S. (1995A): Variation in the quercetin content in different colored onions (Allium cepa L.) owing to location, growth stage and soil type. J. Amer. Soc. Hortic. Sci., 120, 909-913.

Patil, B.S., Pike, L.M. \& Hamilton, B.K. (1995B): Changes in quercetin concentration in onion (Allium cepa L.) owing to location, growth stage and soil type. New Phytol., 130, 349-355.

Prakash, D., Singh, B.N. \& Upadhyah, G. (2007): Antioxidant and free radical scavenging activities of phenols from onion (Allium cepa). Fd Chem., 102, 1389-1393.

Rhodes, M. \& Price, K. (1996): Analytical problems in the study of flavonoid compound in onions. Fd Chem., 57, $113-117$.

Sellappan, S., Aкoh, C.C. \& Krewer, G. (2002): Phenolic compounds and antioxidant capacity of Georgia-grown blueberries and blackberries. J. Agric. Fd Chem., 50, 2431-2438.

Slimestad, R., Fossen, T. \& Vagen, I.M. (2007): Onions: a source of unique dietary flavonoids. J. Agric. Fd Chem., 55, 10067-10080.

Wang, S.Y., Chen, Сн.T. \& Wang, Сн.Y. (2009): The influence of light and maturity on fruit quality and flavonoid content of red raspberries. Fd Chem., 112, 676-684.

Wiczkowski, W., Németh, K., Buciński, A. \& PiskutA, M.K. (2003): Bioavailability of quercetin from flesh scales and dry skin of onion in rats. Polish J. Fd Nutr. Sci., 53, 95-99. 